\title{
第12回＼cjkstart放射線技術シンポジゥム予稿
}

（於 伊香保温泉 福一旅館）

（全部口述発表で 1 題 8 分）

\section{Digital Subtraction Angiography の臨床利用について}

座長 知野今朝人（信州大学）

\section{Digital Subtraction Angiogrphy の 画像解析}

国立循環器病センタ一放射線讋療部

○早崎正信・田中 勲

Digital Subtraction Angiography (DSA) は, X線イ メージ・インテンシファイア (I.I.)一TVカメラ系を $\mathrm{X}$ 線検出器として用い, TV カメラ出力信号を digital 信 号に変換し，画像データを処理した後表示する方法で急 速に進歩しつつある。

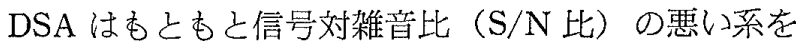
対象とし良い像をいかにして得るかというととが, DSA 開発の重要な課題であったが, detector としての I.I.-TV 系の性能向上，画像処理による像の改善等がピークをむ 汃つつある. DSA で得られる画像の空間分解能ある いは濃度分解能は，本質的に TV カメラ出力信号を得 た段階でほとんど決まってしまう。

よって，乙の系の性能向上が画質を大きく左右する. 今回は，DSAの現状を紹介すると共に，DSA画像に影 響する因子 (特に TV一カメラ出力信号) について検討す 万.

\section{Digital Subtraction Angiography} （DSA）の画質に影響する因子の検 討 一 X 線管, TV-Camera, I.I.を 中心に-

リハビリテイションセンター 鹿教湯病院糡療放射線科

○中沢利隆・和方良成 金井洋一・北沢由利 信州大学医学部放射線医学教室

春日敏夫
Digital subtraction angiography（DSA）における， 画質に影響する因子は，misregistration artifact による 画像の劣化だけでなく，X線管，TV-camera，I.I. な ぞの撮影系，および，撮影テクニックによるものが大き な要素として考えられる。. 今回，われわれは，angio imager YKO-3000 を治験する機会を得たが, DSA 像に おいて, 当初, I.I.のイメージ周辺に, 白と黒の疑輪郭 を思わせる円形の線，またサチレーション防止に含鉛ゴ ムを置いた場合，含鉛ゴムの辺縁に，白と黒の線が表わ れたことについて，DSA装置のシステムの中で，X線管 球，TV-camera，I.I. を個々亿交換し，白と黒の疑輸郭 の原因について検討を行なった。

その結果，X線管による線量の変化，TV-camera に よる性能の違い沈よるものではなく, I.I. の過渡現象に よって起しるものと考えられ, misregistration artifact 之は, 全く別な物理的なむので, どの I.I. であ起こり得 る一般的な現象であると思われる。との対策は I.I.によ って異なると思われるが，物理的な原因による artifact の成因として重要なものとして挙げられる.

3. DSA の被曝線量, コントラスト分 解能，拡大撮影の検討

九州大学医学部附属病院放射線部 ○東丸廣文・新開英秀・馬場 仁 田中順一・楪 秀樹・西水誠治 佐藤春夫・西村弘幸・小川和久 森山有相

検討項目および方法：装置：シーメンス angiotron

1. 被暴線量：ランドファントムに TLD 素子を㧴入 して測定し DSA の場合とAOT に上る通常の血管造影 撮影の場合を比較した.

2. コントラスト分解能：試作血管ファントムとアク 
リル板を用いて，(1)造影剤濃度とコントラスト，(2)ファ ントム厚とコントラスト，(3)入射線量とコントラストの 関係を調べた。

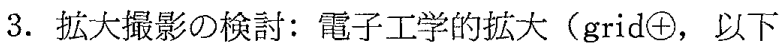
zooming という) と幾何学的拡大 (grid $\ominus$ ) の場合を比 較検討した。比較内容は，(1)線量，(2)コントラスト，(3) 鮮鋭度, (4)ROC, (5)ウイナースペクトルとした。

結果抢よび考察：1. 被写体表面位置での線量はDSA が AOT 撮影の場会の約 3 〜 俈であった。目的部位外 の線量は，DSA の場合，AOT 撮影 (15枚) と比べて， 水晶体は少なく，生殖腺は多かったが，乙れはDSA が PA 方向撮影で AOT が AP 方向撮影による 影響が大で あると考えられた。

2. コントラスト分解能は，ファントム厚に影響され るが厗さ $15 \mathrm{~cm}$ の場合血管径 $2 \mathrm{~mm}$ で約 $1 \%, 1 \mathrm{~mm}$ で $3 \%$ 程度であった。また線量による差はあまり認められ なかった。

3. 拡大撮影については, 拡大率 1.44 倍 (I.I. サイズ 12インチを 9 インチサイズに zooming 亡同一拡大率) では zooming がややよく，2.05 倍（同 7 インチサイズ 亿 zooming 相当）では逆転して 幾何学的拡大の方が良 くなった。また幾何学的拡大の方が線量を40〜60\%程度 に低減できるので臨床的に有用である。

\section{DSA に関する臨床応用への技術的 諸問題}

\author{
藤田学園保健衛生大学病院 \\ ○沢思武司・木野村豐 \\ 并田義宏・藤井茂久
}

近時，DSA はとれまでの侵襲性の大きな X線検查で ある直接動脈造影やシネ冠動脈造影撮影飞代わり得る検 査法として, 注目をあびとの $2 \sim 3$ 年で著しく普及して きた。

しかむ，最近は当初の静脈造影剂注入による動脈造影 法のみならず，直接動脈撮影する方法までが施行されて いる.

本検査法は，現在の所フィルム法に較ベて，空間分解 能は劣るが反対に濃度分解能が高く, 簡篻に血管造影が 実施できる利点がある，したがって，乙の特街を十分に 把握し, 利点を最大限に発揮するような吟味が必要であ る.さらに，採来 DSA の臨床応用を拡げるために，画 質を良くし装置の操作性を高い6のにする等の改善努力 が必要である。

ここに，私共が使用している ADAC 社製 DPS 4100
型をもとに，1．便用装置の I・I tube の輝度計測. 2 . air gap 法と grid 法による DSA 像の比較. 3. bolus 物 質の利用につにて.4. 被曝線量について等の問題点に 検討を加え，若干の成果を得たので報告する。

\section{Digital Subtraction Angiography における撮影手技の検討}

\author{
国立循環器病センター放射線䛦療部 \\ ○東儀英明・粟井一夫・若松孝司
}

Digital Subtraction Angiography（以下 DSA こ略す） は，経静脈性および動脈性により，血管造影を行い, subtraction 像が得られる新しい検査法である. 当セン ターにおいても, DSA の検查を行って約2.5年経過し， その間に1500例以上の検査を行ってきた，検查部位によ り経静脈㧍よび動脈で行う。

また，DSA の画質在左在する因子は，X線管 I.I. TV カメラ系, digital memory 抢よび data を集録するVTR 等があり, 特に I.I., TV カメラ系が重要である. あと1 つは，DSAの撮影手技の方法である．從来の（cine， AOT, Puck 等) 拡大撮影同様にDSA に执ても拡大 撮影を行うことにより，空間分解能を高く，コントラス 卜を良くすることができる。今回は，乙のようなとこに ついて報告する.

\section{6. フィルタについて}

石川䢙立中央病院放射線部

○北野喜文・杉村光洋 田中宏明・伊藤隆康

被写体厚や，吸收差については，DSA 装置の補正回路 により，均等な黑化度のサブトラクション像が得られる ようになっている。

しかし，それが著しい時は補正回で完全にカバーしき れないのが現状である。また被写体が複雑な形をしてい る時，多重絞りのみでは不充分である.

そのような時，フィルタ，X線遮蔽板を使用した方が， より診断価值の高い像が得られる.

当院では，I.I., 6，9，12インチ，オーバーチューブ型 X線テレビ装置で，すべて透視モードでDSA 走行って いる。透視条件は， $70 \mathrm{kV}$ 前後，100 mA または $50 \mathrm{~mA}$, 減光フィルタは，13\%，25\%，50\%である。

特に I.I. 12インチの時は, 視野が大きいため, 被写体 厚差，吸収差，多重絞りで遮蔽できない所，等の影響を うけやすい，その時，フィル夕が必要になる。当院です 以前は天板上，または患者上に，フィルタ，または鉛ゴ 